\title{
Study and Evaluate the Effect of Marketing Mix on Export Performance (Case Study: Nestle Corporation in Qazvin Province)
}

\author{
LOTFIFARD Shohreh ${ }^{13}$, BOROJERDI Peyman Nouri ${ }^{14}$
}

\begin{abstract}
As a success of enterprises within the national boundaries depend on effectiveness and correct marketing, when activity domain of an enterprise develops outside the boundaries, reach to success depends on correct understanding of the foreign market coordinates and adapting proper strategies to manage it. The main challenges of export marketing include choosing proper market and/or countries through marketing research and make decision about how to express marketing mix strategy. The decision more than anything is influenced by the philosophical foundation accepted to the firm about how the activity will be in the foreign market. Thus, the object of research is to study and evaluate the effect of marketing mix on export performance in Nestle Co. Research method was survey-descriptive approach.

Statistical population of the research included managers and experts of Nestle Company.

Sampling has been conducted in simple random sampling approach. It has been used descriptive statistics, inferential statistics, one-sample t-test, linear regression, and analysis of variance to analyze data. Results showed that marketing mix (product, place, price, promotion) has a positive and significant effect on export performance.
\end{abstract}

Keywords: Product, Place, Price, Promotion, Export Performance

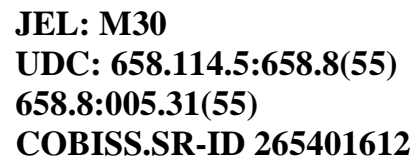

\section{Introduction}

Once marketing rules have been determined and defined by looking out from within the company. Taken years, companies have found that they have to treat within the company from outside needs to grow and develop themselves. Many companies do not still know game rule and they persist to sell their product without any attention to customer needs. Marketing and concepts related to marketing have faced with many changes in the current age. Customerorientation has taken attention of current age organizations because customer has become as selector due to the production surpassed demand. Survival and development of today's organization depends on their customer satisfaction.

\footnotetext{
${ }^{13}$ Abhar Branch, Islamic Azad University, Zanjan, Iran

${ }^{14}$ Abhar Branch, Islamic Azad University, Zanjan, Iran
} 
Today, marketing is not based on production facilities but on the provision of customer satisfaction. This approach develops new concepts related to market and change game rule to sell production/services. Companies and organizations must properly identify and understand their customer needs, tastes, and expectations so that they can produce a maximum value product for the customer; then, they can effectively price, deliver, and promote it and finally they can easily sell that product. In the research, marketing mix has been studied as a main and effective factor in customer purchase behavior and export performance (Mehrani et al., 2012).

On the other hand, enhancement of globalization has forced organizations to review and redefine issues that help them to develop competitive advantage. In an environment where there is the bombardment of ads, promotions, and weekly or even daily discounts and output quality of companies' production line are experiencing extraordinary convergence, reveals the importance of export more than ever and introduces to focus and rethink its mechanisms as an undeniable necessity (Sha Yang, 2004).

In recent years, regarding economical-political situation and sanctions against Iran in the field of oil and international trade, our need to develop exports and more entry to the global markets has become increasingly important and the development of non-oil exports have seriously necessitated. To describe this process, it must be said that the development of export will lead to continuity in production, development of new investment, and the development and keeping existing employment. All these will lead to the realization of economic development. Therefore, this should be taken more attention from various aspects. In the current condition, situation of non-oil exports is in crisis mode in the country. Our country (Iran) has great potential in this field and it can take important steps in this industry through correct planning and proper marketing strategies and consolidate its position in the global arena. This is a necessity while many industries of our country have high potential to enter into global markets and they can obtain competitive advantage through appropriate global planning when compared with competitors (Mohammadian et al., 2013).

Despite the importance of exports, national policies of countries about the movement of goods between countries have been always inconsistent.

Governments are encouraging exports through offering subsidies and indirect supports.

Indirect export support includes tax breaks and government's extensive support programs toward education and development of exports. At the enterprise level, export creates growth and development opportunities for the companies.

Company can reach a higher level of production by the expansion of access to foreign markets. This leads to the unit cost reduction and the achievement of higher interest rate.

According to the increasingly growing the importance of export performance, we have been studied the effect of marketing mix on export performance in Nestle Company.

Therefore, the main objective of the research is to study the effect of marketing mix on export performance in Nestle Company.

\section{Marketing mix}

Marketing mix, marketing components, marketing combination, marketing tools, and marketing tactics all are terms which have been used for marketing mix. Mix or combination means that there should be a coordinated and systematic approach among these components so that they can be effective on influencing and convincing customers. In other words, as customer point of view, the appropriate product with affordable price acts together with all proper distribution and application of communication methods. If any of these components inconsistent with others, the results will be reduction of effectiveness and efficiency of the complex which will prevent the company to achieve objectives. However, tactic or tool means 
that these factors are tool or instrument of companies for campaigning in the market and achieving more success than competitors (Ranjbaran, 1999).

\section{Product}

The product means a combination of products and services which the company offer to the market. The subsets include product variety, design quality, features, brand, packaging, size, services, warranties, support, return, etc. (Mc Carthy, 1960).

\section{Price}

The amount of money that customer must pay for a product which subsets include price list, discounts, special assistance, the period of payment, credit condition, etc. (Mc Carthy, 1960).

\section{Promotion}

Promotion means activities that the company will do to be able to provide buyers with good information about value and desirability of the product so that they buy the product offered by us among products existed in industry. Its subsets include advertisement, public relation, sales promotion, personal selling, and direct marketing (Mc Carthy, 1960).

\section{Place}

Place means activities that the company do to make the product available to the considered consumers. Its subsets include distribution channel (wholesale, retailer, agency, branch), range of coverage, mixing and matching product, inventories, transportation, logistics, etc. (Mc Carthy, 1960).

\section{Literature review}

Jafarizadeh et al., (2012) have been studied the effect of export marketing mix and marketing capabilities on export performance of enterprises. Results show that environment pressure had a positive and significant effect on the tendency to competitors and the tendency to innovation while it had not a significant effect on the tendency to customers and tendency to cost control. Moreover, tendency to customers and tendency to cost control had a positive and significant effect on marketing capabilities while other variables included tendency to competitors and tendency to innovation had not a significant effect on marketing capabilities.

On the other hand, competency of exports and attractiveness of export markets had a positive and significant effect on marketing mix while export markets management and similarities had not a significant effect on export marketing mix. Furthermore, marketing capabilities has a positive and significant effect on export performance while export marketing mix had not a significant effect on export performance. Export dependency could adjust the effect of marketing capabilities on export performance.

Tajedini et al., (2014) have been conducted a research entitled "study the relationship between strategic inertia and export performance (case study: exporting enterprises in Tehran Province)." Findings of the research show that the most Iranian export enterprises have faced with a type of inertia in the marketing strategy arena. This is one of the reasons of instability in the field of export performance of enterprises. Other findings show that there is a significant relationship between adapting the components of marketing mix with enterprises' strategies and export performance. According to the results, enterprises which there was a strategic compatibility between their main strategies and marketing strategies, would have more stable export performance. 
Mohammadi Khoshno et al., (2009) have been conducted a research entitled "study the effect of marketing mix on the enhancement of exporting Iranian hand-woven carpets according to market segmentation (artistic and commercial carpets)." Results show that as a respondent view, four main components of marketing mix of Iranian hand-woven carpets affect on the enhancement of this good export in each artistic and commercial segment but the effect of three components (product, price, and promotion) is different in artistic and commercial segments. The effect of "price component" in the commercial segment was more than in the artistic segment. Conversely, the effect of "product and promotion components" in the artistic segment is more than in the commercial segment. Results of ranking indices in each above segment show that as a respondent view, the effect of indices (including tissue health, lint gender-based pricing, row meter of the carpet, method of personal selling, direct marketing, and supply through more penetration into the current hand-woven carpet markets) on the enhancement of export is more than other indices in the artistic segment. Furthermore, the effect of indices (including carpet elegance and fitness as customer view, reduction of final cost of carpet in the country, increasing supply points through entry to new geographical markets and professional exhibitions in foreign markets (target market) on the enhancement of export is more than other indices in the commercial segment.

Haghighi et al., (2008) in the research entitled "identify the determinant factors of export performance in foodstuffs" have been studied ten factors including size of company, export experience, export incentives, export problems, competitive advantages, export obligation, product adaptation strategy, price adaptation strategy, direct export channels, and foreign advertisement costs toward contribution in export development and export marketing in the field of foodstuffs. In order to gather related information about the factors, developed questionnaire has been distributed among export producing foodstuffs companies in Tehran Province; then, it has been analyzed using structural equation modeling. Hypotheses of the research confirmed the significant relationship between ten factors and export performance in theses companies.

Mohammadian et al., (2013) have been conducted a research entitled "study the effect of market-oriented export and competitive advantage on export performance (case study: Iranian top exporters in 2011)." In the research, the potential effect of market-oriented exporters and competitive advantage on export performance has been studied. Population included Iranian top exporters in 2011 whom are annually introduced by Industry, Mine, and Trade Ministry and Trade Development Organization on the occasion of National Export Day.

Results show that market-oriented export affects on export performance and competitive advantage. Moreover, competitive advantage, which is also a mediator variable between market-oriented export and export performance in the conceptual framework of the research, has a positive effect on export performance.

Shekarchizadeh and Sadat Qoreishi (2012) have been studied the efficacy of marketing mix on the enhancement of sales and market share of Melli Shoe Company in Tehran City.

Results show that hypotheses of the research have been confirmed with $95 \%$ confidence level. It means that as a customer view, marketing mix (P4) affects on the enhancement of sales and market share in Melli Shoe Company. Moreover, the effect of marketing mix variables on increasing sales is prioritized by product, price, place, promotion, respectively.

Yousefi et al., (2014) have been conducted a research entitled "study the effect of product component of marketing mix on increasing the sale of Koohrang Mineral Water Co. in Shar-e kord." It has been demonstrated that diversity, quality, design, features, brand, size, and packaging have a direct relationship with increased sales of Koohrang Mineral Water Company. According to the results, there are provided proposals for each of the seven studied variables to improve sales trend. 
Yousefpour (2014) have been conducted a research entitled "evaluate the effective marketing mix on customer buying decision (case study: probiotic cheese of Pegah Milk Co. in East Azerbaijan Province)." The results showed that marketing mix following by distribution has higher priority than other aspects as customer view.

Geravand et al., (2010) have been conducted a research entitled "the effect of marketing mix on customer buying decision and satisfaction in Production Cooperative Companies of Kuhdasht County." They concluded that customer satisfaction is a function of variables such as quality, price, promotion, and place which as intervening variables lead to purchase decision from these companies by creating and providing customer needs.

Moghimi (2010) has been conducted a research entitled "study the effective components of marketing mix to attract customer into bodybuilding gym in Isfahan City." They concluded that as studied people view, four components such as employees, place, product, and facilities had the most effect on attracting customer and marketing of bodybuilding gym in Isfahan City.

According to the priority of components; employees, place, facilities, product, process, price, promotion, respectively, in sport marketing of gym have significant difference between the female and male point of view regarding observed components. Product, place, facilities, process, price, and promotion to prioritize the components of marketing mix are influenced to attract customers into bodybuilding gym.

Raj \& Arokiasamy (2012) have been conducted a research entitled "the effect of marketing mix and customer perception on brand loyalty". They concluded that components such as price, visual memory, distribution, and promotion have a significant effect on brand loyalty.

Poh Ailing (2006) have been conducted a research in order to study the effect of marketing mix on customer satisfaction in retailing of a mall in Malaysia. They concluded that marketing mix has a significant effect on customer satisfaction.

Chen Green (2009) in a research entitled "marketing mix and brand: competitive strategy of hypermarket" has been analyzed more the marketing mix of retailing and dimensions of brand for similarities of purchase behavior between women and men. In the research, distribution intensity, communicating with brand, and brand equity were considerably higher in men than in women.

According to the literature review, following hypotheses have been developed:

The main hypothesis

\section{Marketing mix affects on export performance of Nestle Co.}

Secondary hypotheses

The first secondary hypothesis: quality and diversity of product affect on export performance of Nestle Co. Co.

The second secondary hypothesis: price of product affects on export performance of Nestle

The third secondary hypothesis: promotion programs affect on export performance of Nestle Co. Co.

The fourth secondary hypothesis: product place affects on export performance of Nestle

Considered variables are established in a form of conceptual model as figure 1 that was adapted from the model of Doaee \& Hosseini (2008). 
Independent variables

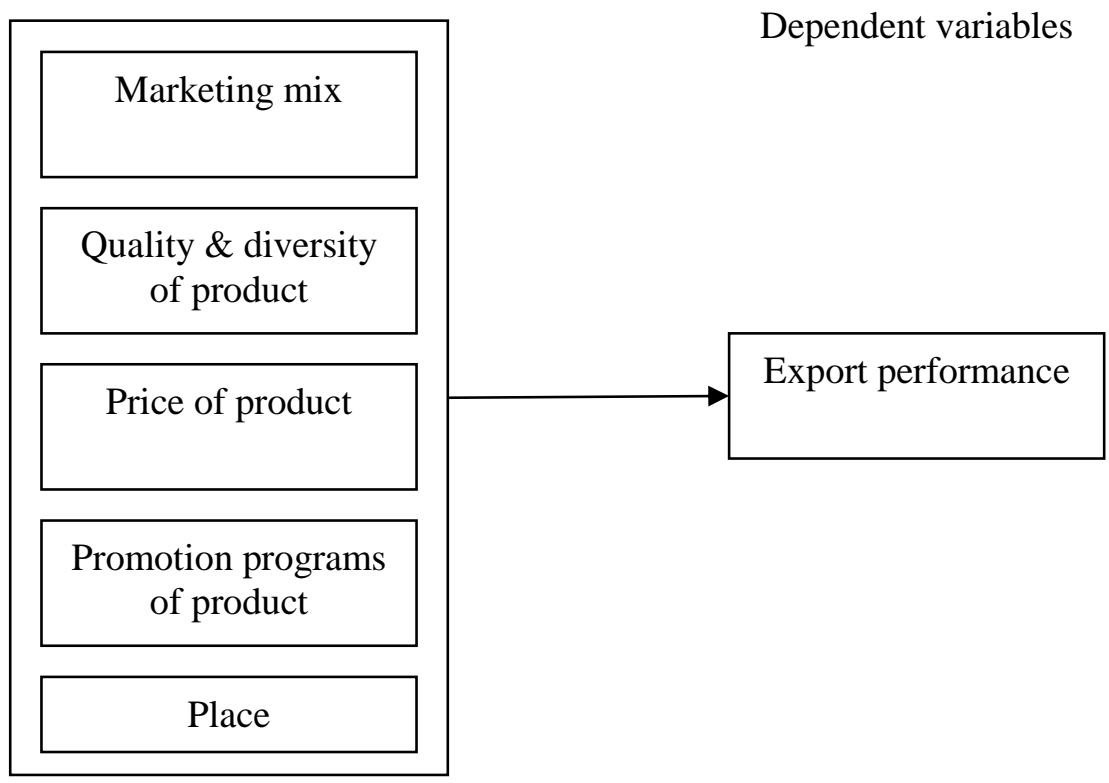

Fig. 1. The conceptual framework of the research Source: Doaee \& Hosseini (2008)

\section{Methodology}

Type of research is applied research in terms of objective, descriptive-survey in terms of the features of subject and time of gathering data. It has been used fieldwork to gather data.

Tools of gathering data were questionnaire.

Questionnaire has been personally distributed among respondents. To obtain required validity in the design and the use of questionnaire, it has been first taken place primarily study about the subject. Then, it has been completely involved to study this subject and their results.

Then, a questionnaire was provided. This suggested questionnaire was submitted to the guidance professor and related exports. After the involvement of their reformed comments, final questionnaire has been developed and submitted to the customers. In addition, it has been used the Cronbach's Alpha to measure reliability of the questionnaire. Questionnaire is of high reliability because the amount of Cronbach's Alpha of all variable is more than 0.7. statistical population of the research included managers and experts of Nestle Company whom the number were 115 people in 2016. Sample size has been calculated 89 people using Cochran formula for limited populations. Members of sample have been selected with simple random sampling.

\section{Findings}

\section{Analyze findings}

In order to use statistics technique, it should first determine the type of gathered data distribution. If data distribution is normal, it can use parametric test for testing hypotheses. If data distribution is not normal, it can use non-parametric test for testing hypotheses. As a 
result, it has been used Kolmogorov-Smirnov test to evaluate the result of data distribution for each variable.

Table 1. The results of Kolmogorov-Smirnov test

\begin{tabular}{llllll}
\hline & Product & Price & Promotion & Place & $\begin{array}{l}\text { Export } \\
\text { performance }\end{array}$ \\
\hline $\begin{array}{lllll}\text { Number } \\
\text { Kolmogorov- }\end{array}$ & 82 & 82 & 82 & 82 & 82 \\
Smirnov & 1.296 & 1.350 & 0.861 & 1.083 & 0.987 \\
Significance level & 0.070 & 0.052 & 0.449 & 0.191 & 0.285 \\
\hline
\end{tabular}

As shown in table.1, the significance level of Kolmogorov-Smirnov test is more than 0.05 so data can be considered normal. Therefore, the null hypothesis based on the normality of data distribution is confirmed. It can use parametric tests for testing hypotheses in spss 16 software. Therefore, it has been used linear regression test for testing each hypothesis in the research.

\section{Explain and interpret variables of the research}

According to the normality of data distribution, it has been used one-sample t-test with test value $=3$ and $95 \%$ confidence level (5\% error) in order to explain and interpret variables of the research. In the test, if the value is greater than $5 \%$, studied variable will have significant difference with P-value $(=3)$ of the test so studied variable is not existed in population at the average level. If the value is less than $5 \%$, studied variable will not have significant difference with P-value $(=3)$ of the test so studied variable is existed in population at the average level.

Table 2. The results of one sample t-test for variables and indices

\begin{tabular}{lllllll}
\hline Factor & $\begin{array}{l}\text { P-value } \\
\text { (Sig. } \\
\text { tailed) }\end{array}$ & Mean & T & $\begin{array}{l}\text { Standard } \\
\text { deviation }\end{array}$ & Minimum & Maximum \\
\hline Product & $\mathbf{0 . 0 0 0}$ & $\mathbf{3 . 9 8 2}$ & $\mathbf{8 7 . 4 6 5}$ & $\mathbf{0 . 4 1 2}$ & $\mathbf{3 . 8 9 2}$ & $\mathbf{4 . 0 7 3}$ \\
Price & $\mathbf{0 . 0 0 0}$ & $\mathbf{3 . 9 1 6}$ & $\mathbf{1 0 7 . 9 1 8}$ & $\mathbf{0 . 3 2 8}$ & $\mathbf{3 . 8 4 4}$ & $\mathbf{4 . 9 8 8}$ \\
Promotion & $\mathbf{0 . 0 0 0}$ & $\mathbf{3 . 9 2 9}$ & $\mathbf{9 8 . 9 8 9}$ & $\mathbf{0 . 3 5 9}$ & $\mathbf{3 . 8 5 0}$ & $\mathbf{4 . 0 0 8}$ \\
$\begin{array}{l}\text { Place } \\
\text { Export }\end{array}$ & $\mathbf{0 . 0 0 0}$ & $\mathbf{3 . 8 5 5}$ & $\mathbf{9 2 . 1 5 5}$ & $\mathbf{0 . 3 7 8}$ & $\mathbf{3 . 7 7 2}$ & $\mathbf{3 . 9 3 8}$ \\
performance & $\mathbf{0 . 0 0 0}$ & $\mathbf{3 . 9 8 5}$ & $\mathbf{8 3 . 8 0 1}$ & $\mathbf{0 . 4 3 0}$ & $\mathbf{3 . 8 9 0}$ & $\mathbf{4 . 0 8 0}$ \\
\hline
\end{tabular}

According to table.2, following results have been obtained:

- According to the respondent, the product variable was significant (significant level is less than $0.05(\mathrm{P}<0.05)$ with 3.982 mean which was higher than average so it is existed in the population in a good condition.

- According to the respondent, the price variable was significant (significant level is less than $0.05(\mathrm{P}<0.05)$ with 3.916 mean which was higher than average so it is existed in the population in a good condition.

- According to the respondent, the promotion variable was significant (significant level is less than $0.05(\mathrm{P}<0.05)$ with 3.929 mean which was higher than average so it is existed in the population in a good condition.

- According to the respondent, the place variable was significant (significant level is less than $0.05(\mathrm{P}<0.05)$ with 3.855 mean which was higher than average so it is existed in the population in a relatively good condition. 
- According to the respondent, the export performance variable was significant (significant level is less than $0.05(\mathrm{P}<0.05)$ with 3.985 mean which was higher than average so it is existed in the population in a good condition.

\section{Testing hypotheses of the research}

According to the normality of data distribution, it has been used linear regression to test hypotheses.

Table 3. The results of fitness of regression model for hypotheses of the research

\begin{tabular}{|c|c|c|c|c|c|c|}
\hline Hypothesis & Regression model & $\begin{array}{l}\text { Square } \\
\text { sum }\end{array}$ & df. & $\mathbf{F}$ & Sig. & $\begin{array}{l}\text { Durbin } \\
\text { Watson } \\
\end{array}$ \\
\hline Main & $\begin{array}{l}\text { The effect of marketing mix } \\
\text { on export performance } \\
\text { The effect of product quality }\end{array}$ & 13.065 & 80 & 11.985 & 0.001 & 2.223 \\
\hline $1^{\text {st }}$ & $\begin{array}{l}\& \text { diversity on export } \\
\text { performance }\end{array}$ & 12.842 & 80 & 13.580 & 0.000 & 2.295 \\
\hline $2^{\text {nd }}$ & $\begin{array}{l}\text { The effect of product price } \\
\text { on export performance }\end{array}$ & 14.126 & 80 & 5.075 & 0.000 & 2.347 \\
\hline $3^{\text {rd }}$ & $\begin{array}{l}\text { The effect of promotion } \\
\text { programs on export } \\
\text { performance }\end{array}$ & 13.947 & 80 & 6.170 & 0.000 & 2.214 \\
\hline $4^{\text {th }}$ & $\begin{array}{l}\text { The effect of product place } \\
\text { on export performance }\end{array}$ & 13.412 & 80 & 9.604 & 0.000 & 2.372 \\
\hline
\end{tabular}

As shown in tabl.3, the significance level is less than 0.05 for all hypotheses so fitness of regression model is confirmed for them. Given that, the value of $\mathrm{F}$ is significant so the trueness of using regression model is confirmed for all hypotheses.

Table 4. Summery results of linear regression test for testing hypotheses

\begin{tabular}{|c|c|c|c|c|c|}
\hline Hypothesis & Regression model & $\mathbf{R}^{2}$ & $\begin{array}{l}\text { Beta } \\
\text { coefficient }\end{array}$ & Sig. & Result \\
\hline Main & $\begin{array}{l}\text { The effect of marketing mix } \\
\text { on export performance } \\
\text { The effect of product quality }\end{array}$ & 0.13 & 0.361 & 0.001 & Confirmed \\
\hline $1^{\text {st }}$ & $\begin{array}{l}\text { \& diversity on export } \\
\text { performance }\end{array}$ & 0.15 & 0.381 & 0.000 & Confirmed \\
\hline $2^{\text {nd }}$ & $\begin{array}{l}\text { The effect of product price on } \\
\text { export performance }\end{array}$ & 0.06 & 0.244 & 0.000 & Confirmed \\
\hline $3^{\text {rd }}$ & $\begin{array}{l}\text { The effect of promotion } \\
\text { programs on export } \\
\text { performance }\end{array}$ & 0.07 & 0.268 & 0.000 & Confirmed \\
\hline $4^{\text {th }}$ & $\begin{array}{l}\text { The effect of product place on } \\
\text { export performance }\end{array}$ & 0.11 & 0.327 & 0.000 & Confirmed \\
\hline
\end{tabular}

As shown in table.4, the significance level is less than 0.01 for all hypotheses.

Thus, null hypothesis (H0) is rejected and all hypotheses of the research are accepted at $99 \%$ confidence level. According to the results, the effect of marketing mix, product quality and diversity, product price, promotion programs, and place on export performance is confirmed with $0.361,0.244,0.381,0.268$, and 0.327 impact factor (Beta), respectively. 
Therefore, marketing mix, product quality and diversity, product price, promotion programs, and product place can predict and explain $13 \%, 15 \%, 6 \%, 7 \%$, and $11 \%$ variance of export performance, respectively.

\section{Conclusion and Recommendation}

The objective of the research was to study the effect of marketing mix on export performance of Nestle Company. The results of research showed that marketing mix (product, place, price, promotion) has a positive and significant effect on export performance. The first hypothesis of research (product quality and distribution affects on export performance of Nestle Co.) was confirmed. It means that the higher the quality and diversity of product increased, export performance will also improve. The direct effect of chosen attitude and strategy of the organization at operational level is reflected as the degree of change proportional to the external market demand. The effect is particularly obvious in supplying the same or different "product" to the target market. Selecting a part of marketing mix, which differentiation gives the product more competition ability in the foreign market, will become feasible thanks to those marketing researches which be conducted to determine the filed of consumer preferences and expectations in different markets and prioritizing them. For example, the choice between adjusting the size, color, design, or brand of the product with the foreign market tastes or offering a variety range of standards or warranties (expanded part of the product) in these markets can be the result of conducting marketing research. The second hypothesis of research (product price affects on export performance of Nestle Co.) was confirmed. Given the high competition in the foreign markets, the higher product pricing is made as appropriate and correct, export performance will also be improved. The third hypothesis of research (promotion programs affect on export performance of Nestle Co.) was confirmed.

Therefore, companies will be succeeded in foreign markets which consider promotion programs proportional to culture and subculture of destination country. The fourth hypothesis of research (product place affects on export performance of Nestle Co.) was confirmed. The result of the hypothesis was not too unexpected because the company can be successful in its export performance in which products of the company are available for public in the target market, and it will not be feasible but with proper distribution channels.

The results of research are consistent with the results of Mohammadi Khoshno (2009), haghighi et al., (2008), Shekarchizadeh \& Sadat Ghoreishi (2012), Yousefiporu et al., (2014), and Raj (2012) researches.

\section{REFERENCES}

1. Doaee, H.A. \& Hosseini, Z. (2008). The role of mix marketing strategy on export performance of the enterprises (emphasizing on product mix). Journal of Business Studies, No. 32.

2. Geravand, A., Nouraei, M. \& Saei, I. (2010). The effect of marketing mix on customer buying decision and satisfaction in Production Cooperative Companies of Kuhdasht County. Journal of Cooperation \& Agriculture, Vol. 21, No.3, pp. 69-88.

3. Haghighi, M., Firozian, M. \& Najafi Majd, S. (2008). Identify the determinant factors of export performance in foodstuffs. Vol. 1, No.1, pp. 3-20.

4. Jafarzadeh, F., Hajopour, B. \& Rahimi, F.A. (2012). The effect of export marketing mix and marketing abilities on export performance of enterprises. Master Thesis, Shahid Chamran University of Ahvaz, Economics and Social Sciences Department. 
5. Moghimi, A. (2010). Study the effective components of marketing mix to attract customer into bodybuilding gym in Isfahan City. Islamic Azad University of Khorasghan.

6. Mohammadi Khoshno, A., Taherpour Kalantari, H.A. \& Abbasi, M.R. (2009). Study the effect of marketing mix on the enhancement of exporting Iranian hand-woven carpets according to market segmentation (artistic and commercial carpets). Tehran: TMBA Publications.

7. Mohammadian, M., Allahverdi, M. \& Salimi, A. (2013). Study the effect of marketoriented export and competitive advantage on export performance: Iranian top exporter in 2011. Journal of Business Management, Vol. 5, No. 4, pp. 61-78.

8. Raj, A, \& Arokiasamy, A. (2012). The Effect of Marketing Mix and Customer Perception on Brand Loyalty. Journal of Business and Management. 2012, 4, 2: 1.

9. Ranjbaran, H. (1999). Marketing and market management (1st Ed.). Commercial Printing \& Publication Co.

10. Tajedini et al., (2014). Study the relationship between strategic inertia and export performance: exporting enterprises in Tehran Province. Journal of Productivity Management, Year IIV, No. 28, pp. 33-49.

11. Yang, S. Raghubir, P. (2005), Can bottles speak volumes? The effect of package shape on how much to buy. Journal of Retailing, No.81, pp. 269-281.

12. Yousefi Hafshanjani, N., Yousefi Hafshanjani, A. \& Nazari, Sh. (2014). Study the effect of product component of marketing mix on increasing the sale of Koohrang Mineral Water Co. in Shar-e kord. First National Conference on Mineral Water Focused on Production \& Export. Shahr-e Kord: Chaharmahal and Bakhtiari Industry, Mine, and Trade Institute. http://www.civilica.com/Paper-NCMW01NCMW01_010.html.

13. Yousefpour, L. (2014). Evaluate effective marketing mix on customer buying decision: probiotic cheese of Pegah Milk Co. in East Azerbaijan Province. First National Conference on Development of a Comprehensive Strategic Quality on Food Safety. Tehran: Iran Quality Management Association. http://www.civilica.com/Paper-IRANQMS01-IRANQMS01_180.html.

\section{Article history: \\ Received 29 January 2018 \\ Accepted 15 June 2018}

